\title{
THE USE OF GOOGLE ON COMPLETING ENGLISH ASSIGNMENT BY THE STUDENTS' OF ENGLISH EDUCATION DEPARTMENT AT UNIVERSITAS NEGERI MEDAN
}

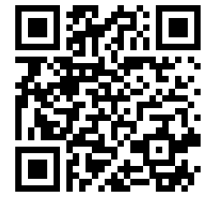

\author{
I Wy. Digeyasa ${ }^{1}$, Lamhot Naibaho ${ }^{2}$ \\ ${ }^{1}$ English Education Department, Universitas Negeri Medan, Indonesia \\ 2 English Education Department, Universitas Kristen, Indonesia
}

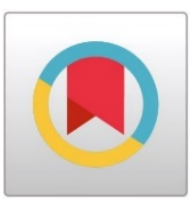

DOI: https://doi.org/10.29121/granthaalayah.v8.i6.2020.457

Article Type: Research Article

Article Citation: A I Wy. Digeyasa, and Lamhot Naibaho. (2020). THE USE OF GOOGLE ON COMPLETING ENGLISH ASSIGNMENT BY THE STUDENTS' OF ENGLISH EDUCATION DEPARTMENT AT UNIVERSITAS NEGERI MEDAN. International Journal of Research GRANTHAALAYAH, 8(6), 150-155. https://doi.org/10.29121/granthaa layah.v8.i6.2020.457

Received Date: 09 May 2020

Accepted Date: 27 June 2020

Keywords:

Google

English Assignment

Completing

Perception

\section{ABSTRACT}

This research is about the use of Google on completing the assignment by the students'. The purpose of doing this research is to find out whether the students use Google on completing their English assignment. It was done at Universitas Negeri Medan exactly in English Education Department. The respondent of this research was the students of 2019 Batch which were taken through purposive randomly sampling. The instrument of this study is a questionnaire which consists of fifteen questions. The result of this study is that that the most of the students (88\%) agree to say that they use Google on completing the English assignment and parts of the students (7\%) strongly agreed to say that they use Google on completing the English assignment, few of the students (4\%) agree to say that they use Google on completing the English assignment for sometimes, and the last is that one of the students were completely disagreed to say that he uses Google on completing the English assignment. Then it is concluded that the students' perception of Google lies on its practicality, interesting, impact, facilities and impact.

\section{INTRODUCTION}

Today, students are very familiar with Google as a search engine to find sources of all information, including students at the Faculty of Language and Arts, especially English Education. Almost all students already use laptops and Androids as a tool that makes it easier for them to learn and also as a tool for communication. By using Google, students can be actively searching the material and doing social media easily because Google could facilitate its users to find any information easier anytime and anywhere. Developments in the global era that occur today are so rapid in all fields of Information in the field of information technology (IT). The era of globalization has a big role in the development of technology that is very fast and makes it easier for users to do activities that were previously more difficult now easier [1], [2]. Internet technology is a resource of information needed by the world to be used accessible to everyone [3], [4]. This phenomenon occurs because between one computer with another computer in the world can be interconnected or communicate.

(C) 2020 The Author(s). This is an open access article distributed under the terms of the Creative Commons Attribution License, which permits unrestricted use, distribution, and reproduction in any medium, provided the original author and source are credited. 
Data or information that in the past took days to process before being sent to the other side of the world, is now done in seconds. This phenomenon is due to the presence of the internet that supports computer technology and telecommunications to be faster with the presence of a website as a provider of communication media services [5], [6], [7]. Google was the result of a project produced by Stanford University students Larry Page and Sergey Brin in early 1966 who developed a search engine that used related mathematical analysis. This initial system is called BackRub, Google is growing rapidly by producing several services such as Gmail, Google Maps, Google Drive and many more, Google is increasingly developing with the rapid development of technology and increasing community needs, seeing Google services accompanied by increasingly rapid technological developments information and much supported by theories of the development of information systems [8], [9], [10].

There are many models developed to measure the acceptance of information systems by users, is the Technology Acceptance Model (TAM). Developing an information technology needs to consider the construct of perceived usefulness and perceived ease of use of the information technology user [11], [12], [13]. The use of Google among students has become a trend in doing assignments and other things; therefore, the use of Google certainly has positive and negative impacts on students. Even today, it can be seen that the use of Google has influenced people's lives [14], [15], [16]. Google is a tool that provides a lot of information that can develop students' knowledge about anything, including their ability to speak English, if they maximize the functionality of the features provided by Google [17], [18].

Some sites facilitate students to learn English, such as dictionaries, English idioms, English grammar, etc. Not only that, but Google also facilitates students with all software that can be downloaded and then used to help them in doing whatever they need in daily lessons, so that they can improve their ability in English both listening, reading, speaking and writing. The impact of Google's use in learning as follows: a) Portability - Google's portability enables students to learn practically whenever and wherever in obtaining or taking information courses through their cellphones or PCs because they are brought from class to class or anywhere; b) Collaboration - Google's accessible mobile student and PC allows students to form groups to distribute and add to their knowledge together and share information easily, and this can lead to more successful collaborative learning; c) Motivation - When Google is accessed in large classes it seems students are more involved in the learning process. The use of Google in learning increases the willingness of students to learn. They took the initiative in using the device as a learning tool [19], [20], [21].

English education students will certainly not be separated from the lectures in English. Almost all subjects use books or English-language material. To understand the material, students generally try to understand the material using Google. As educators and students, utilizing the internet for learning is an effort of technological development in the field of education, and one of them is to use the google search site [22], [23]. Google search is a search engine that by entering our keywords will get the desired information. If Google can be utilized properly, it will be very petrified in learning as a medium and learning resource. Google will make it easier for students to obtain subject matter. By using gadget/smartphone media as well as wifi networks and other media, it makes it easy for users to access information anywhere and anytime [24], [25]. Using modern media and learning resources such as the internet aims to provide tangible examples for students, to search for material or cases that are relevant to English subject matter which can be accessed via google search. Choosing learning material using Google must also be adjusted to the topic or material taught by the lecturer.

In this study, researchers wanted to find out students' perceptions of using Google in doing student assignments especially in learning English. Perception refers to a process of receiving decoding spoken, written or signed input [26], [27]. Students' perceptions are generally related to two targets: their perceptions, and perceptions of learning situations. From the explanation above it can be seen that this research is part of second language acquisition [28], [29]. The use of Google in learning English can be categorized as a new system of learning. Language mastery is part of human learning in general, closely related to personality, closely intertwined with a culture of second language learning, involving disruption, the creation of new linguistic systems, and learning discourse and communicative functions of language. Because Google has become a phenomenon nowadays and all students use Google, researchers find out the impact of using Google on students learning English according to their perceptions.

This research is expected to have benefits both theoretically and practically. Theoretically, the benefit of this research is to contribute to second language acquisition using Google in language learning can be considered a learning strategy for students to gain knowledge. Practically, the results of this study are expected to be useful for 
A I Wy. Digeyasa, and Lamhot Naibaho

students to be aware of the positive and negative impacts of Google, so they can develop their abilities in English and they can also avoid the negative impacts.

\section{METHOD}

In this study, researchers used a quantitative approach to survey design as a research method. The instrument used by researchers in collecting data is questionnaire sheets (which consisted of 14 statements). The research was conducted at the Faculty of Language and Art, Medan State University on January 1 - May 1, 2020. The respondents of this study numbered 35 people.

\section{RESULT AND DISCUSSION}

In this part of the discussion, the students' responses on each item of the question were calculated and discussed one by one to find out the result and finally concluding this research. The analysis of each item are as follows:

1st item - I always feel comfortable doing all of my English assignment using Google -The statement shows that almost all respondent stated that they always feel comfortable doing all of their assignment using Google. None of the respondent $(0 \%)$ who said never, none of the respondents $(0 \%)$ who said rarely, none of the respondents $(0 \%)$ who said sometimes, 5 respondents (14\%) who said often and 30 respondents (86\%) who said always. From the analysis, it is known all of the respondents agree to the use of Google in completing their assignment.

$2^{\text {nd }}$ item - Google facilitates me to find any information that I need in completing my English assignment - The statement shows that none of the respondent (0\%) who said never, none of the respondents (0\%) who said rarely, there were 8 respondents (18\%) who said sometimes, 20 respondents (62\%) who said often and 7 respondents (20\%) who said always. From this calculation, it can be seen that most Google users among the English Education Department State University of Medan students said that Google facilitates them to find any information that I need in completing my English assignment.

$3^{\text {rd }}$ item - By using Google, I can learn and deepen my English during learning and completing my English Assignment - The result of the third item shows that none of the respondent $(0 \%)$ who said strongly disagree, one of the respondents $(6 \%)$ who said disagree, there were 3 respondents $(13 \%)$ who said neutral, 13 respondents $(60 \%)$ who said agree and 9 respondents (21\%) who said strongly agree. From the statements of the respondents, it can be seen that most respondents agreed that by using a Google they can learn and deepen my English during learning and completing my English Assignment.

$4^{\text {th }}$ item - I use Google to access online English Apps to complete my English Assignment - The $5^{\text {th }}$ statement shows that none of the respondent $(0 \%)$ who said never, none of the respondents $(0 \%)$ who said rarely, there were 5 respondents (15\%) who said sometimes, 20 respondents (57\%) who said often and 10 respondents (28\%) who said always. From these results, it can be seen that most of the respondents use Google to access online English Apps to complete my English Assignment. After knowing the results of the 4 statements above it can be seen that most of the respondents use Google wherever and whenever and even use it as an aid on completing their English assignment.

$5^{\text {th }}$ item - Using Google, I could complete my English Assignment easily - The results of the answers from the respondents to this statement are $0 \%$ ( 0 respondent) who strongly disagrees, $0 \%$ ( 0 respondent disagrees), $25 \%$ (9 respondents) who answered neutral, 55\% (19 respondents) who answered agree and 20\% (7 respondents) who answered strongly agreed. Most of the respondents agreed and it can be said that smartphones can help students to learn more easily. From the analysis can be seen that most of the respondents agree that they could complete their English assignment easily using Google.

$6^{\text {th }}$ item - I use Google when only I find it difficult to solve the problem of my assignment - The $6^{\text {th }}$ statement shows that 5 persons of the respondent (14\%) who said strongly disagree, 26 persons of the respondents (74\%) who said agree, there were 3 respondents (8\%) who said neutral, 1 respondent (3\%) who said agree and none of the respondents $(0 \%)$ who said strongly agree. From the analysis is known that most of the students disagree to use Google when only I find it difficult to solve the problem of my assignment.

$7^{\text {th }}$ item - Using Google improves my ability in completing all of my English assignment - The $7^{\text {th }}$ statement shows that none of the respondent ( $0 \%$ ) who said never, one of the respondents (3\%) who said rarely, there were 4 respondents (11\%) who said sometimes, 25 respondents $(71 \%)$ who said often and 5 respondents $(14 \%)$ who said 
The Use of Google on Completing English Assignment by The Students' of English Education Department at Universitas Negeri Medan

always. It can be known that most of the students agree to say that using Google improves their ability in completing all of my English assignment.

$8^{\text {th }}$ item - I am very interested to learn English using Google especially on reading various literature in completing my English assignment - The $8^{\text {th }}$ statement shows that none of the respondent $(0 \%)$ who said never, none of the respondents $(0 \%)$ who said rarely, there were 4 respondents (11\%) who said sometimes, 26 respondents $(80 \%)$ who said often and 3 respondents (28\%) who said always. It shows that most of the students agree to say that they are very interested to learn English using Google especially on reading various kinds of literature in completing my English assignment.

$9^{\text {th }}$ item - I use Google not only for completing my English assignment but also improving my abilities on my language skills - The $9^{\text {th }}$ statement shows that none of the respondent $(0 \%)$ who said never, none of the respondents $(0 \%)$ who said rarely, there were 5 respondents (14\%) who said sometimes, 20 respondents (57\%) who said often and 10 respondents (28\%) who said always. This stamen shows that most of the students agree to say that Google not only for completing my English assignment but also improving my abilities on my language skills.

$1^{\text {th }}$ item - Google enriches my reading sources when completing my English assignment - The $10^{\text {th }}$ statement shows that that none of the respondent $(0 \%)$ who said never, none of the respondents $(0 \%)$ who said rarely, there were 5 respondents (15\%) who said sometimes, 20 respondents (57\%) who said often and 10 respondents $(28 \%)$ who said always. It shows that most of the students are agree to say that Google enriches its reading sources when completing my English assignment.

$11^{\text {th }}$ item - Using Google improves the knowledge that helps me complete my English assignment - The $11^{\text {th }}$ statement shows that none of the respondent $(0 \%)$ who said never, none of the respondents $(0 \%)$ who said rarely, there were none of the respondents $(0 \%)$ who said sometimes, 29 respondents $(83 \%)$ who said often and 6 respondents (17\%) who said always. It can be known that most of the students agree to say using Google improves its knowledge that helps me completing my English assignment.

$12^{\text {th }}$ item - Using Google facilitate me to reach my friends to discuss our English assignment - The $12^{\text {th }}$ statement shows that none of the respondent $(0 \%)$ who said never, none of the respondents $(0 \%)$ who said rarely, there were 1 respondent (2\%) who said sometimes, 32 respondents $(92 \%)$ who said often and 10 respondents (6\%) who said always. It shows that most of the respondents agree to say that using Google facilitate them to reach their friends to discuss our English assignment.

$1^{\text {th }}$ item - I often use Google to share my knowledge and experiences in learning English with friends - The $13^{\text {th }}$ statement shows that none of the respondent $(0 \%)$ who said never, none of the respondents $(0 \%)$ who said rarely, there were 5 respondents (14\%) who said sometimes, 23 respondents (66\%) who said often and 7 respondents (20\%) who said always. This statement shows that most of the respondents agree to say that they often use Google to share their knowledge and experiences in learning English with friends.

$1^{\text {th }}$ item - Using Google on completing the English assignment is always entertaining - The $14^{\text {th }}$ statement shows that none of the respondent $(0 \%)$ who said never, none of the respondents $(0 \%)$ who said rarely, there were 2 respondents $(6 \%)$ who said sometimes, 30 respondents $(85 \%)$ who said often and 3 respondents $(9 \%)$ who said always. It shows that most of the respondents agree to say that using Google on completing the English assignment is always entertaining.

$1^{\text {th }}$ item - Using Google is important for me during classes at my university - The $5^{\text {th }}$ statement shows that none of the respondent $(0 \%)$ who said never, none of the respondents $(0 \%)$ who said rarely, there were 1 respondent (3\%) who said sometimes, 29 respondents (83\%) who said often and 5 respondents $(14 \%)$ who said always. It shows that most of the students agree to say that using Google is important for them during classes at their university.

From the interviews it was concluded that behind the portability impact there is a negative impact that can make students addicted to the use of Google because of its easy access in terms of finding resources and references to do their English assignments, making some students not to do assignments such well. It can be said, sometimes they just copy and paste the results of other people's work to answer the tasks requested by the lecturers they are doing. Students become lazy using manual methods to search for information or knowledge, they tend to look for it through the internet, they become lazy carrying thick books, use dictionaries and don't like going to the library. They are more likely to search for information more practically and instantly.

From the result and the discussion above, it is found that the most of the students (88\%) agree to say that they use Google on completing the English assignment and parts of the students (7\%) strongly agreed to say that they use Google on completing the English assignment, few of the students (4\%) agree to say that they use Google on 
completing the English assignment for sometimes, and the last is that one of the students were completely disagree to say that he use Google on completing the English assignment. This data was also supported by the interview result which shows that most of the students tend to use Google on completing the English assignment although it has a negative impact. The student's perception on using Google in completing their English assignment lies on these aspects: a) comfort of using it; b) the facilities being offered by Google; c) the practicality of Google, and d) the importance of Google.

\section{CONCLUSION}

Based on the results of research on the use of Google on completing assignment by the students' of English Education Department at Universitas Negeri Medan was concluded most of the students agree to say that a) Using Google in completing the English assignment is practical because it can be used to study anywhere and anytime; b) Using Google in completing the English assignment is interesting because they can do such collaboration with friends to share knowledge and experiences and information using social media; c) Google has a motivational impact, because by using Google, they are more motivated for it offers them a lot of reading sources that contribute to the complement of their English assignment, and besides, Google is easier, faster, practical, effective and fun; d) Google could improve their knowledge and ability on learning English and especially on completing their English assignment; and e) Google also has a negative side on student learning, that is practicality and effectiveness, Google can be used anywhere and at any time including cheating during exams, not paying attention in class and making students dependent. Students tend to do things instantly and no longer want to bother with carrying heavy books or carrying dictionaries to campus. Most students think that Google makes them lazy to find information or learn manually. They prefer learning with practical and instant.

\section{SOURCES OF FUNDING}

None.

\section{CONFLICT OF INTEREST}

None.

\section{ACKNOWLEDGMENT}

None.

\section{REFERENCES}

[1] Jonassen, D. H., Howland, J., Moore, J., \& Marra, R. M. (2003). Learning to solve problems with technology: A constructivist perspective.

[2] Huang, Y. M., Liao, Y. W., Huang, S. H., \& Chen, H. C. (2014). A Jigsaw-based Cooperative Learning Approach to Improve Learning Outcomes for Mobile Situated Learning. Educational Technology \& Society, 17(1), 128-140.

[3] Gunn III, J. F., \& Lester, D. (2013). Using google searches on the internet to monitor suicidal behaviour. Journal of affective disorders, 148(2-3), 411-412.

[4] Segers, E., \& Verhoeven, L. (2009). Learning in a sheltered Internet environment: The use of WebQuests. Learning and instruction, 19(5), 423-432.

[5] Tate, D. F., \& Zabinski, M. F. (2004). Computer and Internet applications for psychological treatment: update for clinicians. Journal of clinical psychology, 60(2), 209-220.

[6] Wang, Y. (2004). Distance language learning: Interactivity and fourth-generation Internet-based videoconferencing. CALICO Journal, 373-395.

[7] Hayden, L. J., Glynn, S. M., Hahn, T. J., Randall, F., \& Randolph, E. (2012). The use of Internet technology for psychoeducation and support with dementia caregivers. Psychological Services, 9(2), 215. 
The Use of Google on Completing English Assignment by The Students' of English Education Department at Universitas Negeri Medan

[8] Baker, T. R. (2005). Internet-based GIS mapping in support of K-12 education. The Professional Geographer, 57(1), 44-50.

[9] Anderson, A. S. (2008). The Internet: friend or foe when providing patient education?. Clinical journal of oncology nursing, 12(1), 55.

[10] Thatcher, J. B., Loughry, M. L., Lim, J., \& McKnight, D. H. (2007). Internet anxiety: An empirical study of the effects of personality, beliefs, and social support. Information \& Management, 44(4), 353-363.

[11] Jeffrey, L., Hegarty, B., Kelly, O., Penman, M., Coburn, D., \& McDonald, J. (2011). Developing digital information literacy in higher education: Obstacles and supports. Journal of Information Technology Education: Research, 10(1), 383-413.

[12] Avgerou, C. (2008). Information systems in developing countries: a critical research review. Journal of Information Technology, 23(3), 133-146.

[13] Avgerou, C., \& Walsham, G. (Eds.). (2017). Information technology in context: Studies from the perspective of developing countries: Studies from the perspective of developing countries. Routledge.

[14] Bukachi, F., \& Pakenham-Walsh, N. (2007). Information technology for health in developing countries. Chest, 132(5), 1624-1630.

[15] Dedrick, J., Kraemer, K. L., \& Shih, E. (2013). Information technology and productivity in developed and developing countries. Journal of Management Information Systems, 30(1), 97-122.

[16] Roztocki, N., \& Weistroffer, H. R. (2011). Information technology success factors and models in developing and emerging economies. Information Technology for Development, 17(3), 163-167.

[17] Kurbanoglu, S. S., Akkoyunlu, B., \& Umay, A. (2006). Developing the information literacy self-efficacy scale. Journal of documentation.

[18] Baker, E. W., Al-Gahtani, S. S., \& Hubona, G. S. (2010). Cultural impacts on acceptance and adoption of information technology in a developing country. Journal of Global Information Management (JGIM), 18(3), 3558.

[19] Holzmann, V., \& Spiegler, I. (2011). Developing a risk breakdown structure for information technology organizations. International Journal of Project Management, 29(5), 537-546.

[20] Cline, G. B., \& Luiz, J. M. (2013). Information technology systems in public sector health facilities in developing countries: the case of South Africa. BMC medical informatics and decision making, 13(1), 13.

[21] Zhou, W., Simpson, E., \& Domizi, D. P. (2012). Google Docs in an out-of-class collaborative writing activity. International Journal of Teaching and Learning in Higher Education, 24(3), 359-375.

[22] Dumitrache, A., \& Gheorghe, M. (2018). Project-Based Learning. Practical Steps in Completing a Learning Assignment. In the International Scientific Conference eLearning and Software for Education (Vol. 1, pp. 95100). " Carol I" National Defence University.

[23] Carr, N. (2008). Is Google making us stupid?. Yearbook of the National Society for the Study of Education, 107(2), 89-94.

[24] Naibaho, L. (2019). Teachers'roles in English Language Teaching: A Students Centered Learning Approach. International Journal of Research-Granthaalayah, 7(4), 206-212.

[25] Nadeak, B., \& Naibaho, L. (2020). The Effectiveness of Problem-Based Learning on Students' Critical Thinking. Jurnal Dinamika Pendidikan, 13(1), 1-7.

[26] Crystal, D. (2008). Txtng: The gr8 db8. OUP Oxford.

[27] Naibaho, L. (2019). The Effectiveness of Number Head Together Strategy on Improving Students' English Achievement at Xyz School. International Journal of Research-GRANTHAALAYAH, 7(10), 362-370.

[28] Wesley, S. C., Lee, M. Y., \& Kim, E. Y. (2012). The role of perceived consumer effectiveness and motivational attitude on socially responsible purchasing behaviour in South Korea. Journal of Global Marketing, 25(1), 2944.

[29] Nadeak, B., \& Naibaho, L. (2019, November). Investigating the effect of learning multimedia and thinking style preference on learning achievement on anatomy at Universitas Kristen Indonesia. In Journal of Physics: Conference Series (Vol. 1387, No. 1, p. 012116). IOP Publishing. 